\title{
Chapter 4 \\ Climate Policy in Transportation Sector: Role of Carbon Pricing
}

\author{
Kazuyuki Iwata
}

\begin{abstract}
This chapter focuses on climate countermeasures in the Japanese transport sector. We introduce the Japanese complexed automobile tax system and then calculate the Japanese effective carbon rate (ECR) on automobiles. In addition to the discussion of the ECR, this chapter offers a simple examination of the efficiency of electric vehicles (EVs) from the viewpoint of cost-benefit because it is expected that EVs will become the most popular eco-friendly vehicle in the future. Two remarks are found in our analysis. First, although the carbon tax rate on fuel consumption is small in Japan, compared to the European countries, the ECR is rather high. For further improvement of climate policy, the Japanese government should shift its attention to vehicle usage from vehicle purchase and possession. Second, under the basic assumption (i.e., representative owners do not recharge their EVs at home but at outdoor fast chargers), the diffusion of EVs is not an efficient measure for reducing GHG emissions. If owners recharge their EVs at home once of every two charges, the net benefit becomes positive Therefore, the opportunity cost of waiting for recharges is a key factor in whether EVs can play a role in mitigating climate change.
\end{abstract}

Keywords Automobiles $\cdot$ Carbon tax $\cdot$ Effective carbon rate $\cdot$ Life cycle assessment $\cdot$ Electric vehicles $\cdot$ Fast chargers

\section{Introduction}

Automobiles are one of the most important sources of greenhouse gases (GHG) emissions. In Japan, the amount of total GHG emissions was 1.19 billion $\mathrm{t}-\mathrm{CO}_{2}$ in 2017 (Ministry of the Environment, 2019). Of that amount, 0.21 billion t- $\mathrm{CO}_{2}$ (i.e., $17.9 \%$ ) was attributable to the transport sector. Automobiles, including passenger vehicles and trucks, accounted for $86.2 \%$ of the GHG emissions from the transport

\footnotetext{
K. Iwata $(\varangle)$

Faculty of Economics, Matsuyama University, 4-2 Bunkyo-cho, Matsuyama,

Ehime 790-8578, Japan

e-mail: iwata.kazuyu@gmail.com
} 

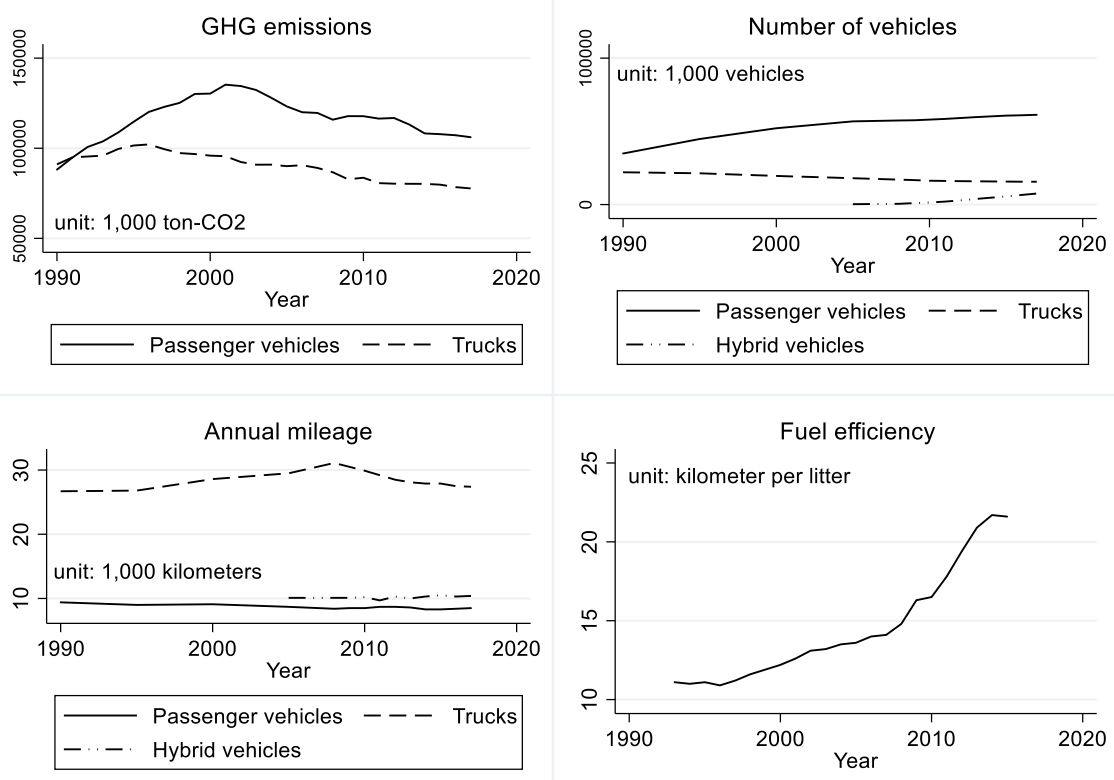

Fig. 1 Trends in GHG emissions and indicators related to vehicles in Japan (The data of the GHG emissions (the top-left panel), number of vehicles (the top-right panel), annual mileage (the bottom-left panel) and fuel efficiency (the bottom-right panel) are obtained from the websites of the Greenhouse Gas Inventory Office of Japan (http://www-gio.nies.go.jp/aboutghg/nir/nir-e.html), the Automobile Inspection and Registration Information Association (https://www.airia.or.jp/publish/ statistics/trend.html), the Survey on Motor Vehicle Transport (https://www.mlit.go.jp/k-toukei/jid ousya.html) and the Ministry of Land, Infrastructure, Transport and Tourism (https://www.mlit.go. jp/common/001178377.pdf), respectively (accessed on December 10, 2019).)

sector. ${ }^{1}$ Therefore, 0.18 billion $\mathrm{t}-\mathrm{CO}_{2}(15.4 \%)$ of the total GHG emissions were generated by automobiles. Although automobiles emit not only the GHG but also air pollutants, this chapter focuses on the GHG only.

Although automobiles are responsible for a large share of GHG emissions, the total amount of emissions has been continuously decreasing since approximately 2000. The top-left panel in Fig. 1 shows the trends in GHG emissions from passenger vehicles and trucks. The emissions peaked in 2002 and 1995 for passenger vehicles and trucks, respectively, and then started decreasing.

What led to the decreased in emissions? There are three potential drivers of the reductions: the total number of vehicles, annual mileage per vehicle and fuel efficiency. The first, the total number of passenger vehicles and trucks (including buses), is presented in the top-right panel in Fig. 1. The numbers of passenger vehicles and trucks have been gradually increasing and decreasing, respectively. The reason why

\footnotetext{
${ }^{1}$ Refer to the following website of the Japanese Ministry of Land, Infrastructure, Transport and Tourism (MLITT): https://www.mlit.go.jp/sogoseisaku/environment/sosei_environment_tk_ 000007.html (accessed on December 10, 2019).
} 
the total number of passenger vehicles has increased is the popularity of hybrid vehicles such as the Prius. ${ }^{2}$ In tandem with the increase in hybrid vehicles, the number of traditional gasoline and diesel passenger vehicles has been decreasing, suggesting that passenger vehicles have been shifting from gasoline and diesel vehicles to ecofriendly hybrid vehicles. Meanwhile, the total number of trucks has continuously decreased since 1990.

The kilometers travelled by passenger vehicles and trucks are shown in the bottomleft panel in Fig. 1. The annual mileage for gasoline passenger vehicles is likely to decrease over time. The decrease may come from increase of aging population because older drivers voluntary limit vehicle usage (Baldock et al. 2006). For diesel trucks, the annual mileage increased until 2008 and then started decreasing. It is thought that this trend may be correlated with Japanese economic conditions. The economic boom lasted until approximately 2009, when the financial crisis happened due to the collapse of Lehman Brothers. After that, the recession started.

The Ministry of Land, Infrastructure, Transport and Tourism shows that the average fuel efficiency of gasoline passenger vehicles is improving over time, suggesting that this improvement has helped to reduce GHG emissions (see the bottom-right panel in Fig. 1). For example, average fuel efficiency in 2015 increased to $21.6 \mathrm{~km} /$ liter compared with $11.1 \mathrm{~km} / \mathrm{liter}, 12.2 \mathrm{~km} / \mathrm{liter}, 13.6 \mathrm{~km} / \mathrm{liter}$ and $16.5 \mathrm{~km} /$ liter in 1995, 2000, 2005 and 2010, respectively. Therefore, in the last 30 years, fuel efficiency has improved approximately twice over. This consistent increase is mainly due to the diffusion of hybrid vehicles.

GHG emissions from vehicles reached a peak in 2001 (see Fig. 1). Although the total amount of emissions has continuously decreased over time, 0.18 billion $\mathrm{t}-\mathrm{CO}_{2}$ in 2017 was still caused by vehicles. To cost-efficiently reduce GHG emissions from vehicles, economic instruments such as emission trading schemes or Pigouvian taxes are the best countermeasures (Kolstad 2010).

For automobiles, it is cost-efficient to impose a Pigouvian carbon tax on gasoline and diesel according to their $\mathrm{CO}_{2}$ coefficients. In 1990, the first carbon tax in the world was implemented in Finland. Then, Sweden introduced a similar tax in 1991. Of course, the two taxes cover gasoline consumption. The World Bank reports that there were 28 countries and regions ${ }^{3}$ where carbon taxes had already been implemented as a carbon pricing initiative by $2019 .{ }^{4}$ In Japan, a carbon tax was introduced in October 2012. The initial tax rates were 250 yen $(U S \$ 2.3)^{5}$ per kiloliter, 260 yen (US\$ 2.4) per ton and 220 yen (US\$2) per ton for petroleum, liquefied natural gas (LNG) and coal, respectively. The government had originally planned to raise the tax rates. Eventually, in 2016, these rates increased by approximately triple, that is, to 760 yen (US\$6.9) per kiloliter, 780 yen (US\$7.1) per ton and 670 yen (US\$6.1) per

\footnotetext{
${ }^{2}$ The Prius was released in 1997 by Toyota as first hybrid vehicle in the world.

${ }^{3}$ Alberta in Canada will abolish its carbon tax in 2020.

${ }^{4}$ Refer to the following website of the World Bank: https://carbonpricingdashboard.worldbank.org/ (accessed on December 10, 2019).

${ }^{5}$ US $\$ 1$ roughly equals to 110 yen.
} 
ton. Automobiles are indirectly affected by this carbon tax because the tax covers petroleum.

The current Japanese carbon tax rates are equivalent to 289 yen (US\$2.6) per $\mathrm{t}-\mathrm{CO}_{2} \cdot{ }^{6}$ Viewing the carbon tax rates among 28 countries and regions, the highest rate is US\$121.3 per $\mathrm{t}-\mathrm{CO}_{2}$ in Sweden. The next highest rate is US $\$ 96.6$ per $\mathrm{t}-\mathrm{CO}_{2}$ in Liechtenstein and Switzerland. Therefore, the carbon tax rate in Japan is relatively low compared with such countries. Another efficient economic instrument is an emission trading scheme (ETS); the carbon prices in the EU ETS and Korea ETS are US\$32.5 and US\$24.2 per $\mathrm{t}-\mathrm{CO}_{2}$ in 2019 , respectively, whereas the price in the Japanese Tokyo $\mathrm{ETS}^{7}$ is only US\$6.0. In addition, firms located outside of Tokyo are not affected by the Tokyo ETS. We observe that the carbon price of the ETS in Japan is also low.

To efficiently reduce GHG emissions and achieve a balance between economic development and implementation of countermeasures against climate change, it is necessary to set appropriate carbon prices using economic instruments such as a carbon tax or an ETS. The efficient carbon price should be set to be equal to the social cost of carbon (SCC). Although many studies have estimated the SCC, there are large differences among them. In a recent study, Wang et al. (2019) reviewed 578 estimates of the SCC from 58 studies (the range is between US\$-13.38 and US\$2386.91 per $\mathrm{t}-\mathrm{CO}_{2}$ ) and concluded that the SCC is US $\$ 54.7$ per $\mathrm{t}-\mathrm{CO}_{2}$, on average. As mentioned above, the Japanese total carbon price is US\$8.6, which sums the US\$2.6 for the carbon tax and US\$6.0 for the Tokyo ETS. The value is obviously lower than the SCC of Wang et al. (2019). Therefore, it may appear that the Japanese government should raise its carbon price to mitigate climate change.

However, several types of taxes besides carbon taxes and ETS costs are already imposed on most goods. For example, many counties impose a value-added tax (VAT) as a consumption tax, and a gasoline tax is often levied on the usage of vehicles. Although the purpose of such taxes is not to prevent climate change but to secure governmental financial resources, such taxes indirectly play the same role as a carbon tax or ETS. The expanded carbon price, which is the sum of carbon taxes, ETS costs and such indirect taxes, is called the effective carbon rate (ECR) (OECD 2016).

In Japan, the ECR for automobiles is complicated because the automobile tax system is not simple. Therefore, this chapter will introduce the Japanese automobile tax system and then calculate the Japanese ECR on automobiles. In addition to the discussion of the ECR, this chapter offers a simple examination of the efficiency of electric vehicles (EVs) because it is expected that EVs will become the most popular eco-friendly vehicle in the future. The IEA (2019) reports that EVs are developing at a rapid pace. For example, the number of EVs was more than 5.1 million in 2018, compared to 3 million in 2017. The report concludes that the market share of EVs

\footnotetext{
${ }^{6}$ Refer to the following website of the Japanese Ministry of the Environment: https://www.env.go. jp/policy/tax/about.html (accessed on December 10, 2019).

${ }^{7}$ The Tokyo ETS does not cover automobiles but covers facilities including office buildings and industrial plants.
} 
Table 1 Automobile tax system in Japan

\begin{tabular}{|c|c|c|c|c|}
\hline Behavior & Tax & Frequency & Note & Rate $(\%)$ \\
\hline \multirow[t]{2}{*}{ Purchase } & $\begin{array}{l}\text { Vehicle } \\
\text { acquisition } \operatorname{tax}^{\mathrm{a}}\end{array}$ & Only once & & $0-3$ \\
\hline & $\begin{array}{l}\text { VAT on vehicle } \\
\text { purchase }\end{array}$ & Only once & & 10 \\
\hline \multirow[t]{3}{*}{ Possession } & Vehicle tax & Every year & $\begin{array}{l}\text { For vehicle with } \\
\text { displacement over } \\
661\end{array}$ & \\
\hline & Light vehicle tax & Every year & $\begin{array}{l}\text { For vehicle with } \\
\text { displacement under } \\
660\end{array}$ & \\
\hline & $\begin{array}{l}\text { Vehicle weight } \\
\text { tax }\end{array}$ & Once every two years & & \\
\hline \multirow[t]{5}{*}{ Usage } & Gasoline tax & Each time & For gasoline vehicle & \\
\hline & Diesel oil tax & Each time & For diesel vehicle & \\
\hline & $\begin{array}{l}\text { VAT on fuel } \\
\text { purchase }\end{array}$ & Each time & & \\
\hline & Carbon tax & Each time & & \\
\hline & $\begin{array}{l}\text { Petroleum coal } \\
\text { tax }\end{array}$ & Each time & & \\
\hline
\end{tabular}

${ }^{\text {a }}$ The vehicle acquisition tax was greatly revised on October 2019. Before the revision, the tax rate was fixed at $3 \%$

will be $30 \%$ by 2030 . In addition, Japan Post Holdings stated in a press release that it will introduce $1200 \mathrm{EVs}$ for use in delivery service by 2020 , implying that $30 \%$ of delivery vehicles in Tokyo will be EVs. ${ }^{8}$

\section{ECR on Automobiles in Japan}

\subsection{Automobile Tax System}

Before calculating the ECR in Japan, this section provides an overview of the automobile tax system. A summary of the tax system is shown in Table 1. In October 2019, the tax system for vehicles drastically changed. Briefly, the tax rate for eco-friendly vehicles decreased.

The tax system for vehicles in Japan consists of taxes on three behaviors: purchase, possession and usage. Suppose that people buy a new or an old vehicle and use it. They must pay various taxes in addition to the vehicle and fuel costs. First, they

\footnotetext{
${ }^{8}$ Refer to the following newspaper website of Asahi Shimbun: https://www.asahi.com/articles/ASM CF4RRPMCFULFA016.html (accessed on December 10, 2019).
} 
must pay two types of taxes on vehicle purchase: vehicle acquisition tax and VAT. These taxes are imposed only once. The vehicle acquisition tax rate is set to $0 \%$, $1 \%, 2 \%$ or $3 \%$, according to vehicle environmental performance characteristics such as fuel efficiency. The tax rate for EVs is set at the lowest rate of $0 \%$ because their environmental performance is better than those of conventional vehicles. Vehicles with low performance face higher tax rates. The VAT rate was fixed at $10 \%$ after October 2019. ${ }^{9}$ When a person purchases a new vehicle at a price of 1 million yen (US\$9091) and the vehicle acquisition tax rate is $2 \%$, (s)he needs to pay 20,000 yen (US\$182) and 100,000 yen (US\$909) for the vehicle acquisition tax and VAT, respectively.

The second type of tax is on vehicle possession. Vehicle owners have an obligation to have a legal inspection of their vehicles carried out once every two years to use them on the road. If vehicles do not pass inspection, they cannot be used on the road. Owners must pay vehicle taxes or light vehicle taxes every year for their vehicles to be considered eligible for inspection. If they forget to make the payment, the vehicles cannot be inspected, meaning that they cannot travel on the road. Which tax is applied depends on the displacement of the vehicle. When the displacement is more than $661 \mathrm{cc}$, the vehicle tax is applied. Otherwise, the light vehicle tax is applied. Even when vehicle owners do not use their vehicle at all, they are required to pay this tax because it is on vehicle possession. The greater the vehicle displacement is, the higher the annual amount of the vehicle tax. ${ }^{10}$ The tax amount increases for every $500 \mathrm{cc}$ of displacement. For example, the tax amount for passenger vehicles with a displacement of $1000 \mathrm{cc}$ is 25,000 yen (US\$227) a year, whereas the amount for passenger vehicles with a displacement of $3000 \mathrm{cc}$ is 50,000 yen (US\$455) a year. Different from the vehicle tax, the amount of the light vehicle tax is fixed at 7200 yen (US\$65) a year. ${ }^{11}$

In addition to the vehicle tax or light vehicle tax, all vehicle owners must pay the vehicle weight tax when a legal inspection is carried out. The first inspection occurs 3 years after a new vehicle is purchased, and then the following inspections occur every 2 years. Therefore, vehicles will undergo inspections and owners will pay the vehicle weight tax at 3, 5, 7 and so on years thereafter. As the name suggests, the tax rate depends on the vehicle weight. The greater the vehicle weight, the higher the tax rate is. For example, the standard tax amounts for passenger vehicles with weights of 1000 and $2000 \mathrm{~kg}$ are set to 16,400 yen (US\$149) and 32,800 yen (US\$298), respectively. In addition to the weight, the tax rates change according to the environmental performance and vehicle age. For the case of a passenger vehicle with a weight of $1000 \mathrm{~kg}$ and high environmental performance, the tax amount decreases from 16,400 yen (US\$149) to 10,000 yen (US\$91). In contrast, for a passenger vehicle with the same weight and age of 18 (i.e., a very old vehicle), the tax amount increases from

\footnotetext{
${ }^{9}$ The VAT rate was $8 \%$ before September 2019.

${ }^{10}$ The vehicle tax amount varies across vehicle type and purpose of use. The tax amount shown here is for passenger vehicles for personal use.

${ }^{11}$ The light vehicle tax amount also depends on vehicle type and purpose of use. The tax amount shown here is for passenger vehicles for personal use.
} 


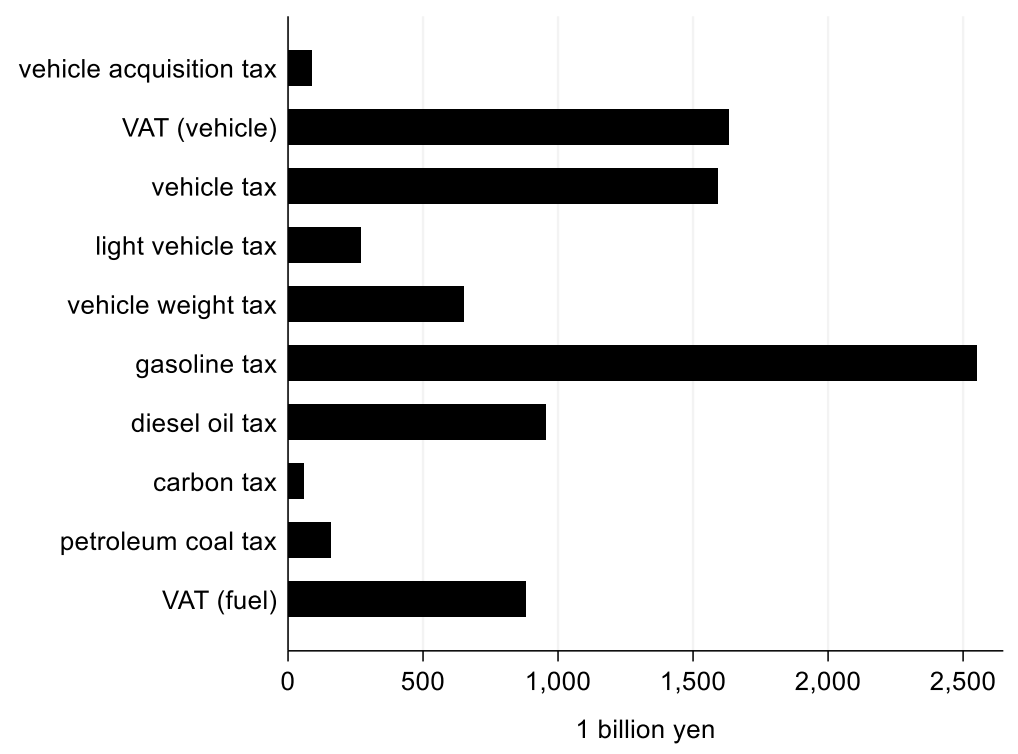

Fig. 2 Tax revenues from each tax related to automobiles in 2018

16,400 yen (US\$149) to 25,200 yen (US\$229). The vehicle tax and light vehicle tax are local tax, whereas the vehicle weight tax is a national tax.

Gasoline or diesel is necessary to use vehicles. The third type of tax is on fuel consumption. The retail price for gasoline includes the gasoline tax, petroleum coal tax and carbon tax. In addition to these three taxes, vehicle users pay VAT when purchasing gasoline, meaning that they pay 4 taxes when using gasoline vehicles. For diesel vehicles, users pay diesel oil tax instead of gasoline tax. The gasoline tax and diesel tax rates are 53.8 yen (US\$0.49) and 32.1 yen (US\$0.29) per liter, respectively. The petroleum coal tax and carbon tax are imposed on all oil and coal products, including gasoline and diesel oil. The petroleum coal tax is 2.04 yen (US\$0.02) per liter, and the carbon tax is 0.74 yen (US\$0.01) per liter, implying that these tax rates are relatively smaller than the gasoline tax and diesel oil tax rates. In particular, the carbon tax rate is much smaller than the other conventional fuel taxes.

Figure 2 presents the revenue from each tax in $2018 .^{12}$ The tax revenues of the carbon tax and petroleum coal tax are calculated from the tax rates and consumption data. The data are obtained from the Survey on Motor Vehicle Fuel Consumption. The other revenues are quoted from the website of the Japan Automobile Manufacturers Association. ${ }^{13}$ The total amount of tax revenue was approximately 8829 billion yen (US $\$ 80.3$ billion). The revenue from the carbon tax was only 58 billion yen (US $\$ 0.52$ billion), which indicates that the carbon tax is of less importance from the viewpoint

\footnotetext{
${ }^{12}$ For the tax revenues from the petroleum coal tax and carbon tax, the 2017 values are used.

${ }^{13} \mathrm{http} / / /$ www.jama.or.jp/tax/outline/image_01.html (accessed on December 10, 2019).
} 
of tax revenue. The most important revenue source is the gasoline tax, followed by the VAT on vehicle purchase and the vehicle tax.

\subsection{Actual ECR After Consideration of the Tax System}

The described 10 types of taxes are levied on vehicle possession and usage in Japan. In this subsection, we simulate and discuss how much GHG emissions vehicle owners generate and pay taxes on from the perspective of a life cycle assessment. For the simulation, we assume that Japanese drivers are average passenger vehicle owners.

Each car owner drove $6300 \mathrm{~km}$ in 2018 (Sony Assurance, 2018). The average fuel economy of gasoline passenger vehicles is $21.9 \mathrm{~km}$ per liter (MLITT 2017). Therefore, the average car consumes $287.7 \mathrm{~L}$ of gasoline per year. Using the $\mathrm{CO}_{2}$ emission coefficient of $2.348 \mathrm{~kg}-\mathrm{CO}_{2}$ per gasoline liter presented by the IEA (2011) yields an equivalence of approximately $676 \mathrm{~kg}-\mathrm{CO}_{2}$ per year. The Automobile Inspection \& Registration Information Association (AIRIA) reports that the average number of years of passenger vehicle usage in 2018 was $13.24 .{ }^{14}$ Therefore, the lifetime total amount of GHG emissions is approximately $8943 \mathrm{~kg}-\mathrm{CO}_{2}\left(=676 \mathrm{~kg}-\mathrm{CO}_{2}\right.$ per year $\times$ 13.24 years). With a social discount rate of $4 \%$ (MLITT 2018) on the total amount of the emission, the present discounted emission is $7112 \mathrm{~kg}-\mathrm{CO}_{2}$. After 13.24 years, we assume that the owners scrap their vehicles.

The average gasoline retail price in 2018, 149.9 yen per liter, was obtained from the Survey on Petroleum Product Price by the Agency for National Resources and Energy. The average owner annually spends approximately 43 thousand yen on gasoline. Over the long term, the total amount of gasoline consumption costs approximately 571 thousand yen.

The average vehicle price is assumed to be 2525 thousand yen (US\$23.0 thousand), which is the average value of the prices of the Note (2131 thousand yen; US\$19.4 thousand), Aqua (2314 thousand yen; US\$21.0 thousand) and Prius (3132 thousand yen; US\$28.5 thousand) car models. These were the top three best selling cars in 2018. ${ }^{15}$ In the same manner, the weight and displacement of the average vehicle are set to $1212 \mathrm{~kg}$ and $1497 \mathrm{cc}$, which are the averages of the weights and displacements, respectively, of these three described vehicles. The characteristics of the assumed average vehicle are shown in Table 2.

Hereafter, we calculate how much owners of the average vehicle pay for the various taxes over the 13.24-year life cycle. We ignore scrapping cost in the calculation. The calculation results are presented in Table 3 . The rows in the table denote the vehicle age, so row 14 indicates the final year, when vehicles are scrapped. The owners,

\footnotetext{
${ }^{14}$ https://www.airia.or.jp/publish/file/r5c6pv000000m20m-att/r5c6pv000000m211.pdf (accessed on December 10, 2019).

${ }^{15}$ In 2018, the best-selling vehicle was the Note, produced by Nissan; 136,324 vehicles were sold. The next best sellers were the Aqua and Prius, manufactured by Toyota. The sales volumes of the Aqua and Prius were 126,561 and 115,462, respectively.
} 
Table 2 Features of the assumed average vehicle

\begin{tabular}{|c|c|c|c|}
\hline Terms & Value & Unit & References \\
\hline Annual mileage & 6300 & $\mathrm{~km} / \mathrm{year}$ & Sony Assurance (2018) \\
\hline Fuel efficiency & 21.9 & $\mathrm{~km} / \mathrm{litter}$ & MLITT (2017) \\
\hline $\mathrm{CO}_{2}$ coefficient & 2.348 & $\mathrm{~kg}-\mathrm{CO}_{2} /$ litter & IEA (2011) \\
\hline Vehicle price & 2525 & thousand yen & $\begin{array}{l}\text { Average retail price among Note, Aqua and } \\
\text { Prius }\end{array}$ \\
\hline Vehicle weight & 1212 & $\mathrm{~kg}$ & Average weight among Note, Aqua and Prius \\
\hline Vehicle displacement & 1497 & $\mathrm{cc}$ & $\begin{array}{l}\text { Average displacement among Note, Aqua and } \\
\text { Prius }\end{array}$ \\
\hline Years of vehicle usage & 13.24 & years & AIRIA website \\
\hline Gasoline price & 149.9 & yen/litter & The survey on petroleum product price \\
\hline
\end{tabular}

Table 3 Amount of tax payments until vehicle scrapping (unit: thousand yen)

\begin{tabular}{l|l|l|l|l|l|l|l|l}
\hline \multirow{2}{*}{ Year } & \multicolumn{2}{l}{ Purchase } & \multicolumn{2}{l}{ Possession } & \multicolumn{2}{l}{ Usage } \\
\cline { 2 - 9 } & $\begin{array}{l}\text { Vehicle } \\
\text { acquisition } \\
\text { tax }\end{array}$ & $\begin{array}{l}\text { VAT on } \\
\text { vehicle } \\
\text { purchase }\end{array}$ & $\begin{array}{l}\text { Vehicle } \\
\text { tax }\end{array}$ & $\begin{array}{l}\text { Vehicle } \\
\text { weight } \\
\text { tax }\end{array}$ & $\begin{array}{l}\text { Gasoline } \\
\text { tax }\end{array}$ & $\begin{array}{l}\text { VAT on } \\
\text { fuel } \\
\text { purchase }\end{array}$ & $\begin{array}{l}\text { Carbon } \\
\text { tax }\end{array}$ & $\begin{array}{l}\text { Petroleum } \\
\text { coal tax }\end{array}$ \\
\hline 1 & 25.3 & 252.5 & 34.5 & 11.2 & 15.5 & 4.3 & 0.2 & 0.6 \\
\hline 2 & 0.0 & 0.0 & 33.2 & 0.0 & 14.9 & 4.1 & 0.2 & 0.6 \\
\hline 3 & 0.0 & 0.0 & 31.9 & 0.0 & 14.3 & 4.0 & 0.2 & 0.5 \\
\hline 4 & 0.0 & 0.0 & 30.7 & 13.3 & 13.8 & 3.8 & 0.2 & 0.5 \\
\hline 5 & 0.0 & 0.0 & 29.5 & 0.0 & 13.2 & 3.7 & 0.2 & 0.5 \\
\hline 6 & 0.0 & 0.0 & 28.4 & 12.3 & 12.7 & 3.5 & 0.2 & 0.5 \\
\hline 7 & 0.0 & 0.0 & 27.3 & 0.0 & 12.2 & 3.4 & 0.2 & 0.5 \\
\hline 8 & 0.0 & 0.0 & 26.2 & 11.4 & 11.8 & 3.3 & 0.2 & 0.4 \\
\hline 9 & 0.0 & 0.0 & 25.2 & 0.0 & 11.3 & 3.2 & 0.2 & 0.4 \\
\hline 10 & 0.0 & 0.0 & 24.2 & 10.5 & 10.9 & 3.0 & 0.2 & 0.4 \\
\hline 11 & 0.0 & 0.0 & 23.3 & 0.0 & 10.5 & 2.9 & 0.1 & 0.4 \\
\hline 12 & 0.0 & 0.0 & 22.4 & 9.7 & 10.1 & 2.8 & 0.1 & 0.4 \\
\hline 13 & 0.0 & 0.0 & 21.5 & 0.0 & 9.7 & 2.7 & 0.1 & 0.4 \\
\hline 14 & 0.0 & 0.0 & 6.9 & 3.0 & 2.2 & 0.6 & 0.0 & 0.1 \\
\hline Total & 25.3 & 252.5 & 365.2 & 71.5 & 163.0 & 45.4 & 2.3 & 6.2 \\
\hline
\end{tabular}

Note Tax rates of the vehicle acquisition tax, vehicle tax and vehicle weight tax are discounted for designated eco-friendly vehicles such as plug-in hybrid vehicles and EVs. The tax rates for eco-friendly vehicles are applied for the calculation 
therefore, pay only a quarter of each tax in the final year because they hold their vehicles for only 0.24 years (approximately 3 months). With a social discount rate of $4 \%$, the present discounted value of the tax payment is 931.4 thousand yen in total. Considering the total discounted emission volume described above, the ECR from the viewpoint of life cycle assessment is 131.0 thousand yen (US\$1.19 thousand) per $\mathrm{t}-\mathrm{CO}_{2}$, implying that the ECR in Japan is considerably higher than the SCC of US\$54.7 per t- $\mathrm{CO}_{2}$ determined by Wang et al. (2019). It is concluded that the Japanese government should reduce the tax rate on automobiles because the ECR is too high.

Of the total payment, 365.2 thousand yen (US\$3.32 thousand), the highest tax payment, is attributable to the vehicle tax. The tax with next highest payment is the VAT on vehicle purchase and then the gasoline tax. When aggregating tax payments by behavior, the tax payments for purchase, possession and usage are 277.8, 436.7 and 216.8 thousand yen (US\$2.07 thousand, US\$3.97 thousand and US\$1.97 thousand), respectively. Therefore, the tax payment for usage is lowest, implying that the Japanese automobile tax system emphasizes taxes on vehicle purchase and possession.

Assuming that the average vehicle features are as shown in Table 2, we calculate the long-term ECR as the total tax payment divided by GHG emissions. If vehicles are assumed to be fuel inefficient, ceteris paribus, the ECR decreases because the denominator becomes larger. If vehicles are assumed to be more expensive, the ECR increases because the numerator becomes larger. These changes are due to the features of the Japanese automobile tax system, where the main tax target is not fuel consumption but vehicle purchase and possession.

GHG emission is not generated from vehicle purchase and possession but usage (i.e., fuel combustion). Therefore, a Pigouvian carbon tax should be imposed on vehicle usage to attain cost efficiency. According to economic theory, the extent of the Pigouvian carbon tax should equal the SCC. Therefore, the Japanese government should shift its attention in the automobile tax system from purchase and possession to usage. At the same time, it should reduce the tax rates on vehicle usage to costeffectively reduce GHG emissions.

Table 4 shows the ECR for an average vehicle. In general, the ECR is calculated by summing taxes on fuel consumption only (OECD 2018), that is, the 4 types of taxes on usage. In this case, the ECR is 30.5 thousand yen (US\$277) per t-CO $\mathrm{CO}_{2}$. The OECD (2016) reports that the Japanese ECR on road vehicles in 2012 was approximately 22.6 thousand yen (US\$205) per t- $\mathrm{CO}_{2}$. Considering that the estimated ECR depends on vehicle characteristics (as in Table 2), our calculated ECR is not greatly different from that of the OECD (2016). Additionally, the difference may come from the

Table 4 The ECR for an average vehicle

\begin{tabular}{l|l|l|r|l}
\hline & Purchase & Possession & Usage & Total \\
\hline Tax payment (thousand yen) & 277.8 & 436.7 & 216.8 & 931.4 \\
\hline Tax payment/GHG emissions (thousand yen/t- $\left.\mathrm{CO}_{2}\right)$ & 39.1 & 61.4 & 30.5 & 131.0 \\
\hline
\end{tabular}


different benchmark years. The benchmark years of this chapter and the OECD (2016) report are 2018 and 2012, respectively.

The OECD (2016) also shows the ECRs for 40 countries, including Japan. The highest ECR, 33.7 thousand yen (US\$307) per $\mathrm{t}-\mathrm{CO}_{2}$, is implemented in the UK. Of the 40 countries, Japan has the 14th highest ECR on road vehicles. That is, although the carbon prices of the carbon tax and the Tokyo ETS in Japan are smaller than those in other countries, it is confirmed that the ECR is sufficiently high compared to the SCC.

\section{Cost-Benefit of EVs in Japan}

\subsection{Construction Cost for Fast Chargers}

After the consideration of the ECR on automobiles in Japan in the previous section, this section conducts a cost-benefit analysis of the diffusion of EVs. Different from previous studies examining the effects of EVs, this chapter explicitly considers the recharging time of EVs, which is a social loss, similar to congestion. The basic concept of the analysis follows the method of Ito and Managi (2015). In this costbenefit analysis, we assume that all vehicles in Japan are substituted by EVs, that is, that there are no conventional gasoline or diesel vehicles. The AIRIA shows that there are approximately 62.1 million vehicles in Japan. ${ }^{16}$ Therefore, our analysis assumes that there are same number of EVs.

Similar to refuelling stations for conventional gasoline vehicles, EVs require fast chargers outside of homes. Of course, frequently charging EVs at home may eliminate the demand for fast charging them elsewhere. However, when EVs travel long distances, fast chargers are always required. Therefore, considering the diffusion of EVs, many new fast chargers must be constructed.

We calculate the required number of fast chargers and their construction costs. The required number of fast chargers can be obtained from the total yearly electric power consumption divided by the yearly electric power supply per charger [Eq. (1)]. In the equation, the term in parentheses denotes the unit. The value of the yearly electric power supply per charger is set to approximately $140,160 \mathrm{kWh} / \mathrm{unit} / \mathrm{year}$, obtained from Mitsubishi UFJ Research and Consulting (2014). The report shows that the fast charger takes $30 \mathrm{~min}$ to charge $8 \mathrm{kWh}$. In other words, the charger takes one year to charge $140,160 \mathrm{kWh}$.

The total yearly electric power consumption is calculated by multiplying the total number of EVs (i.e., 62.1 million vehicles) and the required electric power consumption per EV [Eq. (2)]. On the assumption that drivers' behaviors are not changed by the use of EVs, the required electric power consumption per EV is obtained from the annual mileage (i.e., $6300 \mathrm{~km}$ in Table 2) divided by the EV

\footnotetext{
${ }^{16} \mathrm{https}: / /$ www.airia.or.jp/publish/statistics/ub83el00000000wo-att/01.pdf (accessed on December $10,2019)$.
} 
driving distance per $\mathrm{kWh}$ [Eq. (3)]. We use approximately $9.3 \mathrm{~km} / \mathrm{kWh}$ as the driving distance of the $\mathrm{EV}$, which is equal to the performance of the Leaf model produced by Nissan. ${ }^{17}$ According to the three equations, the required number of fast chargers is 299,069. In the calculation, we assume that all EV owners do not recharge their EVs at home but at fast chargers outdoors. Therefore, the required number can be regarded as the maximum.

$$
\begin{aligned}
& \text { Number of fast chargers }(\text { units }) \\
& =\frac{\text { Total yearly electric power consumption }(k W h / \text { year })}{\text { Yearly electric power supply per charger }\left(\frac{k W h}{\text { unit.year }}\right)}
\end{aligned}
$$

Total yearly electric power consumption $(k W h /$ year $)$

$=$ Total number of EVs(vehicles)

$\times$ Required electric power consumption per EV $\left(\frac{k W h}{v e h i c l e \cdot y e a r}\right)$

Required electric power consumption per EV $\left(\frac{k W h}{v e h i c l e \cdot \text { year }}\right)$

$$
=\frac{\text { Annual mileage }\left(\frac{\mathrm{km}}{\text { vehicle } \cdot \text { year }}\right)}{\text { driving distance of } E V \operatorname{per} k W h(k m / k W h)}
$$

The construction cost of the fast charger is set to 2.25 million yen (US\$20.5 thousand) (Mitsubishi UFJ Research and Consulting, 2014). The statutory useful life for a fast charger is 8 years. ${ }^{18}$ Therefore, ignoring a discount rate, the annual cost per charger is approximately 281 thousand yen (US\$2.26 thousand). The total annual cost for constructing fast chargers is 84.1 billion yen per year (US $\$ 0.76$ billion). The values and data sources in the calculation are shown in Table 5.

\subsection{GHG Emission Reduction}

As mentioned earlier, the amount of GHG emissions from automobiles is 0.18 billion $\mathrm{t}-\mathrm{CO}_{2}$. In the case that all conventional gasoline and diesel vehicles are replaced with $\mathrm{EVs}$, the amount of GHG emissions from fuel consumption becomes zero. Therefore, the direct emission reduction effect of EVs is 0.18 billion $\mathrm{t}-\mathrm{CO}_{2}$.

On the other hand, EVs need electric power. The total yearly electric power consumption of EVs is already calculated in Eq. (2): approximately $42.9 \mathrm{GWh}$ per

\footnotetext{
${ }^{17}$ The Leaf with a $30 \mathrm{kWh}$ battery can travel $280 \mathrm{~km}$ on a full charge; http://history.nissan.co.jp/ LEAF/ZE0/1211/charge.html (accessed on December 10, 219).

${ }^{18}$ Refer to the Next Generation Vehicle Promotion Center website: http://www.cev-pc.or.jp/hojo/ pdf/h31/H23-H24_kouhukitei_saisoku.pdf (accessed on December 10, 2019).
} 
Table 5 Data sources for calculating construction cost

\begin{tabular}{l|l|l|l}
\hline Term & Value & Unit & Source \\
\hline $\begin{array}{l}\text { Yearly electric power supply per } \\
\text { charger }\end{array}$ & 140,160 & $\mathrm{kWh} / \mathrm{unit} / \mathrm{year}$ & $\begin{array}{l}\text { Mitsubishi UFJ Research } \\
\text { and Consulting (2014) }\end{array}$ \\
\hline Total number of EVs & 62.1 & million vehicles & AIRIA website \\
\hline Annual mileage & 6200 & $\mathrm{~km} / \mathrm{year}$ & Sony Assurance (2018) \\
\hline Driving distance of EV per kWh & 9.3 & $\mathrm{~km} / \mathrm{kWh}$ & Nissan website \\
\hline Construction cost of fast charger & 2.25 & million yen/unit & $\begin{array}{l}\text { Mitsubishi UFJ Research } \\
\text { and Consulting (2014) }\end{array}$ \\
\hline $\begin{array}{l}\text { Statutory useful life for fast } \\
\text { charger }\end{array}$ & 8 & years & $\begin{array}{l}\text { Next Generation Vehicle } \\
\text { Promotion Center website }\end{array}$ \\
\hline
\end{tabular}

year. Therefore, that amount of electric power must be newly generated for the use of EVs. Here, the additional electric power is assumed to be generated by thermal power generation (i.e., coal, oil and LNG). Viewing the breakdown of thermal power generation, coal, oil and LNG account for $40.4 \%, 10.8 \%$ and $48.8 \%$, respectively (Agency for Natural Resources and Energy 2018). Therefore, when the power generation amount is apportioned at these rates, 16.9, 4.5 and $20.5 \mathrm{GWh}$ are generated by coal, oil and LNG thermal generation. Since the $\mathrm{CO}_{2}$ coefficients for each type of power generation are 943, 738 and 599 gram- $\mathrm{CO}_{2}$ per $\mathrm{kWh}$, respectively (Imamura et al. 2016), the additional annual total amount of GHG emissions is 31.5 million $\mathrm{t}-\mathrm{CO}_{2}$.

Therefore, the amount of net GHG emission reduction is approximately 0.15 billion $\mathrm{t}-\mathrm{CO}_{2}$ because the reduction in emissions from replacement of other vehicles with EVs exceeds the increase in emissions from the related power generation. When the reduction is converted into monetary value with the SCC at 6017 yen (US\$54.7) per t- $\mathrm{CO}_{2}$ in line with Wang et al. (2019), the annual benefit of reducing GHG emissions from diffusion of EVs is approximately 916.4 billion yen (US\$ 8.33 billion).

\subsection{Opportunity Cost of Recharging Time}

The EV owner must wait for the vehicle to recharge at the charging station. They may do something to work during the recharging time (e.g., input work using a laptop). However, for simplicity, we ignore this possibility. That is, we consider the recharge wait time to be an opportunity cost. Although the charging time has become shorter, Mitsubishi UFJ Research and Consulting (2014) reports that it takes 30 min to fully recharge an EV.

EV owners annually drive $6300 \mathrm{~km}$, and an EV can travel $280 \mathrm{~km}$ on a single charge (see the previous Sect. 3.2). Owners thus recharge their EVs at charging stations 22.5 times a year. The time value of driving is presented in MLITT (2018) 
at 39.6 yen per minute. Following Eq. (4), the annual opportunity cost per EV is 26,730 yen (US\$243).

$$
\begin{aligned}
& \text { Opportunity cost for } E V\left(\frac{\text { yen }}{\text { vehicle }}\right)=\text { recharging time }\left(\frac{\text { minute }}{\text { time }}\right) \\
& \times \text { number of recharges }(\text { time }) \\
& \times \text { time value of driving }\left(\frac{\text { yen }}{\text { vehicle } \cdot \text { minute }}\right)
\end{aligned}
$$

When using conventional gasoline vehicles, owners must refill fuel at refuelling stations. The Fire and Disaster Management Agency reports that the refuelling amount is on average $30.6 \mathrm{~L} .{ }^{19}$ The refuelling speed of the refuelling machine is legally set to between 30 and $35 \mathrm{~L}$ per minute by the Fire Service Act. Using the average speed of $32.5 \mathrm{~L}$ per minute and the average refuelling amount, we can calculate the refuelling time for each refuel as approximately $0.94 \mathrm{~min}$.

Since gasoline vehicle owners consume $287.7 \mathrm{~L}$ of gasoline per year, calculated by the annual mileage (i.e., $6300 \mathrm{~km}$ ) divided by the fuel efficiency (i.e., $21.9 \mathrm{~km}$ per liter), they refuel their vehicles approximately 9.4 times for a year $(=287.7 \mathrm{~L}$ per year/ $30.6 \mathrm{~L}$ ). Therefore, the opportunity cost for conventional gasoline vehicles is approximately 350 yen (US\$3.2), calculated as in Eq. (5). The opportunity cost of refuelling conventional vehicles is quite small compared to that of recharging EVs.

$$
\begin{aligned}
& \text { Opportunity cost for conventional vehicles }\left(\frac{\text { yen }}{\text { vehicle }}\right) \\
& =\text { refuelling time }\left(\frac{\text { minute }}{\text { time }}\right) \\
& \quad \times \text { number of refuels }(\text { time }) \\
& \quad \times \text { time value of driving }\left(\frac{y e n}{\text { vehicle } \cdot \text { minute }}\right)
\end{aligned}
$$

The net opportunity cost of replacing conventional vehicles with EVs is 26,379 yen (US\$239.8). Considering that the number of vehicles is 62.1 million, the total opportunity cost is 1638.2 billion yen (US\$14.9 billion). The data sources for calculating the costs are described in Table 6.

\subsection{Total Net Benefit of EVs}

Three components of EV net benefit have been calculated: the construction cost, the benefit from the GHG reduction and the net opportunity cost. The amounts of those components are annually 84.1 billion yen, 916.4 billion yen and 1638.2 billion

\footnotetext{
${ }^{19}$ Refer to the Fire and Disaster Management Agency website: https://www8.cao.go.jp/kisei-kai kaku/kaigi/meeting/2013/wg/ene/130508/item2-2.pdf (accessed on December 10, 2019).
} 
Table 6 Data sources for calculating opportunity costs

\begin{tabular}{l|l|l|l}
\hline Term & Value & Unit & Source \\
\hline Recharging time & 30 & minute & $\begin{array}{l}\text { Mitsubishi UFJ Research and } \\
\text { Consulting (2014) }\end{array}$ \\
\hline Annual mileage & 6200 & $\mathrm{~km} /$ year & Sony Assurance (2018) \\
\hline Travel distance on a single charge & 280 & $\mathrm{~km}$ & Leaf with 30kWh battery \\
\hline Time value of driving & 39.6 & yen/minute & MLITT (2018) \\
\hline Refuelling amount & 30.6 & litter & $\begin{array}{l}\text { Fire and Disaster Management } \\
\text { Agency website }\end{array}$ \\
\hline Refuelling speed & 32.5 & litter/minute & Fire Service Act \\
\hline Fuel efficiency & 21.9 & $\mathrm{~km} /$ liter & MLITT (2017) \\
\hline
\end{tabular}

yen, respectively. Therefore, the total net benefit is negative, -805.9 billion yen (-US\$73.3 billion), implying that the Japanese government should not promote the diffusion and usage of EVs. This conclusion mainly comes from the fact that the opportunity cost of waiting for EVs to recharge is remarkably large.

The upper bound value of the opportunity cost is calculated in the simulation as mentioned before because all EV owners are assumed not to recharge their EVs at home but at outdoor fast chargers 22.5 times per year. Therefore, we reduce the number of recharges at outdoor fast chargers (i.e., increase the number of recharges at home) and recalculate the cost and benefit. When owners recharge their EVs at home, the opportunity cost of waiting for EVs to recharge is assumed to be zero. For example, this could be because the recharge is performed overnight.

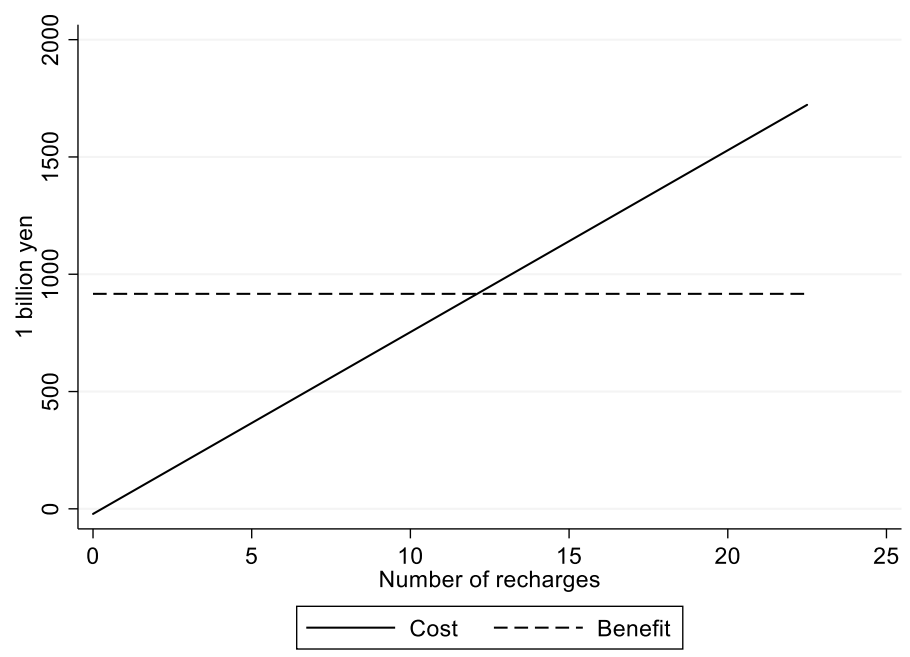

Fig. 3 Cost and benefit of EVs by number of outdoor recharges 
The recalculated costs and benefits are depicted in Fig. 3. The $\mathrm{x}$ - and $\mathrm{y}$-axes represent the number of recharges and monetary value of the cost or benefit, respectively. In the basic simulation, the number of outdoor recharges is set to 22.5. As shown in Fig. 3, we observe that the cost (i.e., sum of the construction cost and opportunity cost of recharge wait time) decreases as the number of outdoor recharges decreases. When the number of recharges decreases to 12 , the benefit is greater than the cost, implying that the promotion of EVs improves social welfare. Twelve is approximately half of 22.5, so if less than one of every two recharges is done outdoors, the spread of EVs will be an efficient countermeasure against climate change. Since charging EVs takes longer than refuelling gasoline or diesel vehicles, it is necessary to examine in particular how many times EV owners will use outdoor fast chargers. In addition, to improve social welfare further, it is important for policymakers and manufacturers to develop high-performance fast chargers.

\section{Concluding Remarks}

Since automobiles greatly contribute to GHG emissions in Japan (i.e., 15.4\% of the total), it is important to examine how to efficiently reduce emissions from automobile. A carbon tax on fuel consumption was implemented in Japan in 2012 to reduce GHG emissions from vehicles. However, the tax rate, 289 yen (US\$2.6) per t- $\mathrm{CO}_{2}$, has been criticized as being too low compared to the rates of other countries and the SCC determined by Wang et al. (2019). However, multiple taxes are already imposed on vehicles in Japan. Considering taxes such as the vehicle acquisition tax and VAT, the entire tax rate on carbon, that is, the ECR, may not be small. Focusing on automobiles in Japan, this chapter first gave an overview of the complicated vehicle tax system and examined the entire ECR on vehicles.

Different from the OECD (2016) and OECD (2018), when calculating the ECR on vehicles in Japan, we consider the entire vehicle tax system, including taxes on vehicle purchase and possession, from the perspective of life cycle assessment. The final ECR on vehicles in Japan is estimated to be 128.9 thousand yen (US\$1.17 thousand) per $\mathrm{t}-\mathrm{CO}_{2}$, suggesting that the ECR is quite large. This is because the tax rates for vehicle purchase and possession are high compared to the rate for vehicle usage under the vehicle tax system in Japan. Therefore, although the carbon tax rate on fuel consumption is small in Japan, the ECR is rather high. For further improvement of countermeasures against climate change, the Japanese government should shift its attention to vehicle usage from vehicle purchase and possession.

Second, we completed a cost-benefit analysis of EVs, which are projected to become a main type of vehicle in the future (IEA 2019). The benefit of EVs is calculated as the monetary value of GHG emissions reduction when all vehicles are replaced with EVs. The cost is the sum of the construction cost of fast chargers and the opportunity cost of the EV recharge wait time. For the basic calculation, we assume that EV owners do not recharge their EVs at home but at outdoor fast chargers. In that case, the cost and benefit are estimated to be 1722 and 916 billion 
yen (US\$15.7 and 8.3 billion), respectively. That is, the diffusion of EVs is not an efficient measure for reducing GHG emissions. However, if owners recharge their EVs at home once of every two charges, the net benefit becomes positive, suggesting that the opportunity cost of waiting for recharges is a key factor in whether EVs can play a role in mitigating climate change. Therefore, it is important for policymakers to examine how often EV owners use outdoor fast chargers as well as to develop higher performance fast chargers. Additionally, to make effective use of the waiting time for recharging, it is desirable to construct fast chargers. This chapter introduces strong assumptions for estimating the ECR and the cost-benefit analysis. Future research needs to relax the assumptions to examine them precisely.

Acknowledgements This chapter was supported by JSPS KAKENHI Grant Numbers 16K13371 and $18 \mathrm{H} 03433$.

\section{References}

Agency for Natural Resources and Energy (2018) Japanese energy 2018: 10 questions to know energy today. https://www.enecho.meti.go.jp/about/pamphlet/pdf/energy_in_japan2018. pdf. Accessed on 10 Dec 2019

Baldock MRJ, Mathias JL, McLean AJ, Berndt A (2006) Self-regulation of driving and its relationship to driving ability among older adults. Accid Anal Prev 38(5):1038-1045

IEA (2011) Carbon dioxide emissions coefficients detail factors. https://www.eia.gov/environment/ emissions/archive/coefficients.php. Accessed on 10 Dec 2019

IEA (2019) Global EV Outlook 2019. https://www.iea.org/reports/global-ev-outlook-2019. Accessed on 10 Dec 2019

Imamura E, Iuchi M, Bando S (2016) Comprehensive assessment of life cycle $\mathrm{CO}_{2}$ emissions from power generation technologies in Japan, Socio-economic Research Center Rep., No.Y06

Ito Y, Managi S (2015) The potential of alternative fuel vehicles: A cost-benefit analysis. Res Trans Econ 50:39-50

Kolstad CD (2010) Environmental economics. Oxford University Press, Oxford

Ministry of Land, Infrastructure, Transport and Tourism (2017) Average fuel economy for gasoline passenger vehicles by JC08 mode. http://www.mlit.go.jp/common/001225518.pdf. Accessed on 10 Dec 2019

Ministry of Land, Infrastructure, Transport and Tourism (2018) Cost-benefit analysis manual. http:// www.mlit.go.jp/road/ir/hyouka/plcy/kijun/ben-eki_h30_2.pdf. Accessed on 10 Dec 2019

Ministry of the Environment (2019) National greenhouse gas inventory report of JAPAN. http:// www-gio.nies.go.jp/aboutghg/nir/2019/NIR-JPN-2019-v3.0_GIOweb.pdf. Accessed on 10 Dec 2019

Mitsubishi UFJ Research and Consulting (2014) Survey on profitability of charging infrastructure development. http://www.cev-pc.or.jp/chosa/pdf/H25_chosa_1_honpen.pdf. Accessed on 10 Dec 2019

OECD (2016) Effective carbon rates: pricing $\mathrm{CO}_{2}$ through taxes and emissions trading systems. OECD Publishing

OECD (2018) Effective carbon rates 2018: pricing carbon emissions through taxes and emissions trading, OECD Publishing

Sony Assurance (2018) Survey on car life in 2018. https://from.sonysonpo.co.jp/topics/pr/resear ch20181203.pdf. Accessed on 10 Dec 2019 
Wang P, Deng X, Zhou H, Yu S (2019) Estimates of the social cost of carbon: A review based on meta-analysis. J Cleaner Production 209:1494-1507

Kazuyuki Iwata is a Professor of Faculty of Economics at Matsuyama University in Ehime, Japan. He is a Ph.D., MA and BA in economics from Sophia university in Tokyo. After the graduation, he has worked as a researcher of Graduate School of Environmental Studies at Tohoku University and then an associated professor of Faculty of Regional Studies at Takasaki City University of Economics. His major is environmental economics and applied economics, and he is particularly interested in empirically evaluating urban and transport policies related to the environment such as air pollution and global warming issues. His research papers have been published in international academic journals such as Transportation Research Part D, Journal of Economic Behavior and Organization, Applied Energy, and Energy for Sustainable Development. He is also a coauthor of An Evaluation of Japanese Environmental Regulation: A Quantitative Approach from Environmental Economics (Springer 2015, coauthored with Dr. Toshi H. Arimura).

Open Access This chapter is licensed under the terms of the Creative Commons Attribution 4.0 International License (http://creativecommons.org/licenses/by/4.0/), which permits use, sharing, adaptation, distribution and reproduction in any medium or format, as long as you give appropriate credit to the original author(s) and the source, provide a link to the Creative Commons license and indicate if changes were made.

The images or other third party material in this chapter are included in the chapter's Creative Commons license, unless indicated otherwise in a credit line to the material. If material is not included in the chapter's Creative Commons license and your intended use is not permitted by statutory regulation or exceeds the permitted use, you will need to obtain permission directly from the copyright holder. 